\title{
Replacing "Whole Limbs with Borrowed Ones": Whiteness, Decolonization, and Early Nationalist Identification
}

\section{Raquel Baker}

California State University

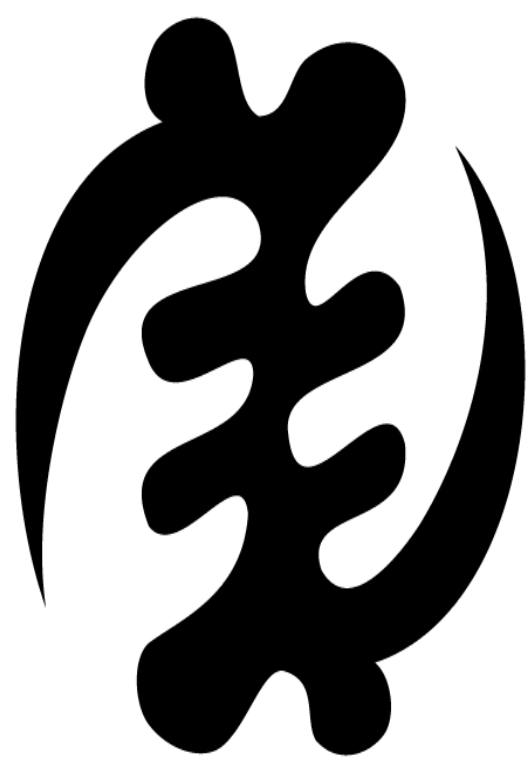

\section{ABSTRACT}

In this essay, I center an examination of the satirical play "The Blinkards," written by Kobina Sekyi in 1915 in the context of British colonization of the Gold Coast in West Africa, present-day Ghana. I show that postcolonial modes of identification emerged within the conceptual framework of cultural nationalism. As such, I argue that emergent postcolonial practices of identification are grounded in transnational modes of modernity. My examination of a selection of Sekyi's texts shows how whiteness structures oppositional selfmaking practices within a colonial context, positioning whiteness itself as a key ground of transnational subject positions that develop in modernity.

\section{KEYWORDS}

Blinkards, Identification, Nationalism, Postcolonialism, Kobina Sekyi, Whiteness 
Once mama said to me when I was about to go again to the predominantly white university, "You can take what the white people have to offer, but you don't have to love them." ... She was speaking about decolonization and the reality of what it means to be taught in a culture of domination by those who dominate. She was insisting on my power to separate useful knowledge ... from participation in ways of knowing that lead to ... alienation. —bell hooks, "Choosing the Margin as a Space of Radical Openness" (206)

By 1915 already the philosopher and sociologist he never ceased at heart to be, [Kobina Sekyi] insisted that society was an organism, living, growing, developing, evolving. It evolved healthily only if it reacted correctly to the stimuli from its changing environment. But in that process it never abruptly replaces whole limbs with borrowed ones, still less annihilates its whole self. -H. V. H. Sekyi, The Blinkards: A Comedy and The Anglo-Fanti-A Short Story (viii)

In the 1916 satire "The Blinkards: A Comedy," Kobina Sekyi presents the tensions inherent in early twentieth-century Cape Coast elite identification. These tensions are created through the ways in which oppositional self-making practices are also grounded in the selfnegating ontological frame of whiteness. In "The Blinkards," Sekyi, who is considered the first Anglophone playwright of the Gold Coast region of West Africa, presents these tensions through the relationships of two camps of characters: those who eschew all things African and try to imitate English practices and those who live in accordance with African traditions-in other words, the white versus the right. The characters in the play represent a sampling of workingclass, middle-class, and elite members of early twentieth-century Cape Coast society, including a merchant, a lawyer, a doctor, a cocoa magnate, a policeman, and fishermen, along with their wives, children, and servants. In the four-act play, Sekyi presents the various insider locations of the social elite and aspiring elite classes from drawing rooms to business offices and garden parties in Cape Coast, showcasing the social dynamics that underwrite whiteness by exploring the relationships between non-traveled, aspiring local elites (Mr. and Miss Tsiba and Mr. Okadu) and Western-traveled and -educated elites (Mr. Onyimdze and Mr. and Mrs. Borofosem). Elites negotiate both whiteness and concepts of custom or tradition to gain legitimacy in local public and private contexts. The aspiring characters internalize and reproduce whiteness as a key locus of identification by conferring power and prestige to the Western-traveled characters through their desire for knowledge about Western practices. For example, Mr. Tsiba brings his daughter, Miss Tsiba, to visit Mrs. Borofosem so she might teach Miss Tsiba what she learned in London and "make her behave like a white lady" (Sekyi 21). Mr. Tsiba's comment reveals a key representational strategy of the play - the figurative conflation of English, British, and European practices to stand in for key notions of African modernity (dignity, access, progress) and aspirational identification - what Mr. Tsiba wants for his daughter, who he wants her to be able to be- "a white lady". My central thesis is that, in the play, Sekyi constructs whiteness as a figure that articulates the key ideological aims of African modernity (liberty, human dignity, sovereignty, and progress) through the character's aspirational identification with whiteness. Sekyi simultaneously reveals the crisis engendered by internalizing a symbolic and ontological system that positions one's cultural traditions as inferior. Sekyi suggests that whiteness as an 
aspirational identification and as a ground for oppositional and anti-colonial consciousness is self-negating.

For Sekyi, aspirational identification with whiteness is tantamount to self-annihilation. The complex and absurd social dynamics performed in the play show how elites negotiate, and in some cases fail to negotiate, their legitimacy by deploying whiteness as a discourse related to acquiring and maintaining power in local contexts in the colonial period. Sekyi's work shows the kinds of visual and ontological idioms used to gain power in local communities. Such visual idioms of power were part of the process of fashioning opposition to the colonial regime. Local authority and oppositional modes of self-making were shaped by a sense of a Fanti-nation state and the construction of Fanti custom, which stood in for a universal sense of "African" custom, as well as upon a visual, and ontological, and discursive engagement with whiteness.

Sekyi's political and literary work presents the development of oppositional and liberated identification in the context of the dynamic commitments and affiliations of early twentiethcentury colonial Gold Coast culture. While whiteness becomes a foundation of these commitments and affiliations, the development of an anti-colonial cultural nationalism simultaneously positions whiteness as a mode of false consciousness, a kind of "flimsy foreign frippery" (Sekyi 21). The alliteration of this phrase uttered by Mr. Borofosem in the play's first act, performs a theatricalness that suggests the conscious construction of a staged self. This rhetorical construction mirrors Sekyi's visual idiom, which connects whiteness to spectacle. First, I suggest a kind of rhetorical spectacle presented in Mr. Borofosem's stilted phrasing. Sekyi's satirical tone connects this staged self to false consciousness, suggesting the play's central paradox: Mr. Borofosem's phrasing performs whiteness, imitates English formality on the discursive or figurative level, while he critiques imitation of "foreign ways" on the denotative level. Mr. Borofosem, wearing his pyjamas and slippers, rails against "blind imitators" who "see a thing done in England, or by somebody white; then say we must do the same thing in Africa" (Sekyi 21). These are the fools who Mr. Borofosem accuses of allowing themselves "to be dazzled by all this flimsy foreign frippery" (Sekyi 21). Mr. Borofosem denounces whiteness as being antithetical to African authenticity, yet this denunciation is itself grounded in a performance of whiteness on both the visual (pyjamas, slippers, smoking a cigar) and semantic (staged phrasing) levels.

The critique lodged on the discursive level is undermined by the visual idiom of the scene--not just the visual idiom of the scene but also the way in which performances of whiteness constitute Mr. Borofosem's most intimate spaces. Mr. Borofosem is critical of the confounded "must-ness" of it all: "They see a thing done in England, or by somebody white," laments Mr. Borofosem, "then they say we must do the same thing in Africa" (Sekyi 21, my emphasis). At the same time, Mr. Borofosem has internalized whiteness, decentering the issue of authenticity and centering the issue of intimacy and intimate belonging. Mr. Borofosem feels at home in pyjamas, slippers, the English language, and white ways of being. "Just fancy that I," Mr. Borofosem states, "a Fanti, should be able to express my thoughts better in English, because I evolved from youth-hood into manhood in England: Then when I want to speak my own language as much as possible, my wife compels me to speak to her always in English" (Seky 21). Perhaps because of his shame, Mr. Borofosem tries to emphasize his wife's guilt but what is at stake here is his sense of being able to express himself best in his performances of whiteness even as he suggests whiteness is inauthentic. In this paradox we find Sekyi's key insight: 
performances of whiteness are simultaneously self-constituting and dissimulating. Whiteness is profoundly authentic, comfortable, and self-negating. This insight constituted through Sekyi's visual and formal poetics is more nuanced than even the ostensible cultural nationalist and satirical message of the play that positions whiteness as only inauthentic.

This inauthenticity is introduced by Mr. Borofosem's opening monologue but is developed and sustained by the key buffoonish character, Mrs. Borofosem. We first see Mrs. Borofosem in her home, again foregrounding the intimate in the performance of and aspiration for whiteness. Mrs. Borofosem's dress, manner, and relationship to her husband positions whiteness as a visual spectacle. The play begins in Mrs. Borofosem's drawing room and opens with her male house servant, a Fanti, wearing English-inspired servant's garb and sweeping up tobacco leaves that dropped onto the carpet from a book he's taken off the shelf. Mrs. Borofosem's first line, spoken in Fanti, "Look here, you idiot, what are you up to? Give me those leaves. You are too much of a bushman," centers the key issue of the devaluation of Africanness that constitutes performances of elite identification and self-making practices (Sekyi 4). Here the use of "bushman" as a derogatory term establishes Mrs. Borofosem's performance of whiteness as self-negating or, perhaps more precisely, constitutes performances of whiteness as negating of African ways of being (Sekyi 4). This devaluation of African practices is visually foregrounded by Mrs. Borofosem's dress in a European dressing gown and lorgnette, eye glasses mounted with a handle that are often worn as jewelry, an accessory of the rich and a sign of ladyhood, distinction, and style in Europe and the United States in the play's contemporary moment. The 1915 American Encyclopedia and Dictionary of Ophthalmology states, "Such a device, manipulated with one hand, can be quickly placed before the eyes and is convenient for momentary use by presbyopes, who thus avoid being burdened with other glasses" (4950). This marker of luxury and everyday practicality - noted in the encyclopedia as a device "of real value"-becomes a marker of inauthentic self-styling for Mrs. Borofosem (4950). Its inauthenticity in relation to Mrs. Borofosem is tied to its Western-ness. The device comes into wide use once the Englishman George Adams creates a practical mounted design that can be carried in the pocket (Rosenthal 118). This device, whose name is derived from the French lorgner (to leer or stare), is what Mr. Borofosem refers to as "flimsy foreign frippery" (Rosenthal 118; Sekyi 21). Mrs. Borofosem perfectly stages the devices relation to spectacle-being leered at or stared at because one presents a problem in the visual field. As such, this image of Mrs. Borofosem in her lorgnette more broadly positions aspirational Africans as "blind imitators" of "a thing done in England, or by somebody white," building the key trope of critical vision and authentic self-styling the lorgnette helps define (Sekyi 22). Mr. Borofosem notes, "My parents set out deliberately to make me as much like a European as possible, before they sent me to England. They would have bleached my skin, if they could. I am rather glad that idiotic American hair-straightening thing did not come out in their time. I am sure they would have got me one: and I should have looked like a mad golliwog" (Sekyi 22). Mr. and Mrs. Borofosem are members of a class who can afford travel and luxury - second generation elite - and whiteness 
frames their self-styling. Most important, this whiteness is related to shame as well as to a misstep in style ${ }^{1}$.

\section{“Don't Be a Bushman”: Hierarchical Difference and Elite Identification}

Hierarchical difference is the key marker that constitutes the logic of whiteness. Sekyi dramatizes the psychosocial issue of adopting English practices because they are perceived to be better than indigenous practices. Act two introduces the public elite spheres of parks and social clubs where key practices of identification for the elite and aspiring elite are constituted through performances of whiteness, beginning with a garden party in Victoria Park, and explicitly invokes the issues of hierarchical difference, hybridity, and transnational blackness. The public setting introduces the issue of surveillance and the scopic economies that characterize representations of whiteness as characters act out at the party and others admonish them to stop causing people to look at them. Act two continues to present the devaluing of African practices to develop the issue of alienation caused by elite condescension toward indigenous cultural practices. For example, at the garden party when one of the girls, Miss Akuma, is speaking to Mr. Onyimdze in Fanti, another girl admonishes her and tells her to speak in English. Miss Akuma responds, "What do you take yourself to be? Do you think, you who only learnt to walk in boots the other day that you are better than I? If you like, let us walk together: do you think you are my equal (Seyki 56)?" Here Sekyi continues to develop the key issue of hierarchical difference as introduced in Mrs. Borofosem's characterization of her house servant as a "bushman".

Sekyi also explicitly introduces the issue of class, as another system of hierarchical difference, in the conversation; in the first scene, the girls relate Mrs. Borofosem's travel to England with being high class, while Mr. Onyimdze back handedly asserts that she reminds him of the lower classes of England. While the women's behavior-speaking in English, dressing in the English style, and playing games - is clearly lampooned by the distinguished and selfpossessed Mr. Onyimdze, this character also subscribes to the logic of whiteness in his framing of (class) difference as hierarchical. In this sense, Sekyi's work poses a more profound issue than the one in which he explicitly aims - the defense of African cultural values - to reveal the conundrum of how the logic of whiteness structures the self-making practices of even the characters who are meant to be models of Africanist and appropriately nationalist thinking. As such, Sekyi reveals how whiteness structures cultural nationalist thinking itself.

Mr. Onyimdze variably refers to himself as a Fanti and a negro who has received mixed education in both the indigenous and English traditions, pointing to the multiple and complex inheritances that traverse his identifications. Further, Mr. Onyimdze suggests that his alienation

\footnotetext{
1 See, for example, Mr. Borofosem's speech, "But I must confess to my shame, that I feel hampered when I put on the native dress, because I do not know how to wear it properly: it is always slipping from my shoulder. That is why I wear pyjamas in the house: they are the freest clothing my wife will permit. Just fancy that I, a Fanti, should be able to express my thoughts better in English, because I evolved from youth-hood into manhood in England" (Sekyi 23).
} 
is a product of his education in English (read unnatural) traditions and further genders this alienation. He states,

To be civilized is to be made effeminate: your wants increase, and your contentment decreases in proportion. The civilized man is a product of man's discontent; but the student of Nature, the truly observant thinker, is one of the most beautiful flowers in Nature's garden. (Seyki 65)

Later, the character Mr. Tsiba uses the term "she-male education" (Sekyi 73). This language again highlights the issue of hierarchical difference. Education is infused with the tension of the two negative associations of being both feminizing and whitening.

The issues raised in the play are explicitly tied to modernity, and in particular how whiteness is involved in practices of constructing difference: For example, when Miss Tsiba becomes pregnant, her father asks a doctor to perform an abortion. The doctor who attends to her discusses racialized difference:

When you come to think of the difficulties I have passed through before I could have patients to operate on, you will get a headache. At first some said they were afraid, others said I couldn't do it, because only white men could operate, black surgeons being scarce. ... When a white surgeon is unfortunate in an operation, nothing is said. If it had been a black man who had had such bad luck, the outcry would be loud and long. (Sekyi 87)

The second scene introduces the Cosmopolitan Club as a space in which members consolidate self-constituting performances of whiteness. The members discuss the practices that mark one as civilized: dressing in the English style, eating English food, and drinking English refreshments. One member reads a treatise that concludes: "To be a gentleman, we must imitate Europeans," and the members pass a code to dress and speak in the English style when in public (Sekyi 107). Given the accretion of meaning, this civility is also tied to femininity, giving it a predominantly negative valence for the audience. The issue of hybridity is again engaged during the reading of Miss Tsiba's wedding invitation as the full name of characters are announced, showing the (ridiculous) mix of Western and indigenous influences: Mr. Aldiborontiphoscophornio Chrononhontonthologos Tsiba and Mr. Alexander Archibald Octavius Okadu. In the third scene, a member of the Cosmopolitan Club rejoices the blessings of being "modern born," in response to a fellow Club member exclaiming, "Ah! Cake is nice: all due to the white man" (Sekyi 113). On the level of language, the dialogue at the wedding reception becomes more ridiculous as the club members praise how European it is.

In the final act, the conflict escalates to the key issue of the sanctity of a church wedding versus native cultural practices, and Miss Tsiba is arrested for bigamy for being married to another man in a native ceremony after being married in the church without having her first marriage legally ended, meaning ending through Western legal processes. Mr. Onyimdze wins the bigamy case, and this conflict serves as a direct critique of the colonial Marriage Ordinance of 1884 (Baku 372). In the second scene, Mrs. Borofosem is attacked in the drawing room by her drunk house servant, who tries to kiss her, a form of greeting she had been obsessed with, despite her husband's discomfort with it, because she saw husbands and wives greet each other in this 
way during her trip to England. Mr. Borofosem enters and stops the attack but in his head chides her for introducing the custom to the house in the first place. In the third scene, Mrs. Borofosem returns to wearing native garb and speaking Fanti in response to the attack. She renounces her previous beliefs, and Mr. Borofosem goes back to wearing native dress. All the major storylines are resolved - native marriage customs are upheld legally, and Mr. and Mrs. Borofosem have gone back to native practices - and the play ends with Mr. Borofosem in his drawing room; he explains he is now more rational in accepting native cultural practices. Two men dressed in the English style enter the drawing room to get help from Mr. Borofosem for the scuffs they received from falling down in the street because they are drunk. The men denounce native practices and praise English ways - the cycle continues. In the play, the characters who espouse English ways receive negative consequences, and the main transformation is the movement of the Borofosems from English to native practices. The overall condescension toward the characters who espouse Englishness suggests a policing of the nouveau riche by the old guard but without the old guard's consciousness of how cultural nationalism is traversed by the logic of whiteness.

Whiteness structures the way in which the characters in Sekyi's work position themselves in relation to themselves, their personal aspirations, and their social networks. Each character's use of whiteness - as aspiration, model, shameful comfort, or defining opposition - constitutes his or her personal identification and social position. The play suggests even more intimate functions of whiteness in grounding social position and a personal sense of savvy and modernity. The text of the play, written in English and Fanti, mixes cultures and languages, suggesting the complex cultural milieu in which cultural nationalist ideas were shaped - a milieu in which whiteness - a signifier of racialized violence, exclusion, and difference; economic marginalization; conditions of access, social mobility, and affiliation; a value system that devalues indigenous subjects, and also the very proof of modernity itself — both enables and limits theories and practices of decolonization.

The play uses whiteness as a symbol of opposition to Africanness in order to consolidate nationalism as a racialized mode of anticolonial identification. The characters' positions within rather than outside of whiteness undergird their ability to make authoritative claims. More important, the ways in whiteness undergirds the characters' attainment of social positioning and belonging - the ways in which the characters feel deeply at home and comfortable in their performances of whiteness (even as the explicit message of the play represents these desires and performances as ridiculous) - suggest a relationship more fraught and complex than inauthenticity. The main message of the play comes in a line uttered by the character Mr. Onyimdze, a young, English-educated lawyer: "Those of our genuine Fanti old men who are proud in every way of their nationality are wiser, healthier, and infinitely more respectable and dignified than those who are anglicized" (Sekyi, 59). In this line, Mr. Onyimdze, who is Westerneducated but prefers native garb, sandals, and speaking in Fanti when he is not working, articulates Sekyi's nostalgic vision in which respectability, dignity, and moral and physical vigor are used to underwrite a notion of nationalism grounded in a conception of authentic Fanti culture. Mr. Onyimdze says this line at a garden party at Victoria Park in the Gold Coast town of Cape Coast while speaking to a group of girls in European clothing who are questioning the morality and respectability of Mr. Onyimdze's behavior, asking “Don't you like English things? Why do you wear native dress? We want you to wear English clothes: you will look very nice. The native dress don't able to cover your right shoulder, so it is naked: it is not nice" (Sekyi, 53). 
Both the girls, who want to be instructed in "Englishness," and Mr. Onyimdze, who walks in the party sneering disapprovingly, "Just look at them," aim to police what constitutes authentic performances of elite identification: one grounded in valuing anglicized ways over indigenous practices and one grounded in critiquing anglicized behavior even as the character holding such a view is himself Western-educated and deeply embedded in the values of his cultural milieu in which Anglicization is promoted as a precursor to having a successful life in terms of respectability, dignity, and access (Sekyi, 40). The emphasis on the girls' broken English develops the trope of inauthenticity and the sense of ridiculousness that characterizes the performances of the Anglophilic characters. However, rather than being dismissed as mimics who can't speak English properly or as pathetic, misguided fools who simply want to be white, Sekyi's characters open up questions about how whiteness functions as a conceptual figure in early Cape Coast anticolonial discourse.

\section{Nationalism as Internalized Whiteness}

In "The Blinkards," Sekyi uses the performative power of theater to animate the identity struggle of Gold Coast elites, a struggle which undoubtedly informed the development of his cultural nationalist thought. As an early example of the literature of West African nationalism, Sekyi's satire aims to reconstruct and uplift Fanti identification by opposing it to colonial whiteness; in the process, the satire critiques whiteness and its ideological structure of white supremacy. One function of the work, as a decolonizing text, is to shift internalized whiteness as the African subject's measure of worth, which requires resisting a larger colonial framework where the colonized's approximation of whiteness is an absolute good - in fact, the only good. In the early twentieth century, cultural nationalism is a form of opposition to colonial rule and black marginalization. It becomes a form a protonationalism - a way to cultivate black pride, black power, and black independence - that becomes invested in state nationalisms throughout postcolonial Africa. The nationalist thought espoused by coastal transnational elites grounded oppositional identification in the representational logic of whiteness. Whiteness as a set of practices, experiences - in this case with elite social spaces, travel, and education-beliefs, and affinities significantly shapes elite anticolonial identification at this nascent moment of nation building, marking modern space as what postcolonial scholar Jemima Pierre calls "an invariably racialized one" (xii). The author's dual recognition of how fundamental whiteness is to the identification practices of the characters functioning within the elite Cape Coast social milieu as well as how uncomfortably it sits with a sense of Fanti pride and the ability to value Fanti culture and history marks the absurd structure of both the play and performances of whiteness. Given that the elite class is working out a new national form of identification marked by negotiations of respectability, consumption of luxury items, "showy tomfoolery," and the essential devaluation of the black subject, performances of whiteness define the dominant mode of elite self-styling and what Pierre terms "racecraft"- "the design and enactment, practice, and politics of race making" (xii). The satire in the play works to show the complexity and ultimate absurdity of the broader situation of fighting for liberation against the British in order to create an independent postcolonial nation but doing so through an identification with whiteness, an identification that undermines the value of the African subject. This logic of whiteness neutralizes the decolonizing impetus of the nationalist agenda by setting it within normative discourse rather than by significantly transforming the discourse and allowing for radical conceptions of tradition, value, identification, and relations with others. 
Sekyi's cultural nationalism aligns with the major components of Pan-African philosophy², which include

Africa as the homeland of Africans and persons of African origin, solidarity among people of African descent, belief in a distinct African personality, rehabilitation of Africa's past, pride in African culture, Africa for Africans in church and state, [and] the hope for a united and glorious Africa. (Esedebe qtd. in Osei-Nyame 138)

The Gold Coast has an intellectual relationship to the roots of Pan-Africanism, which institutionally begins with a conference held in London in 1900 that includes an African representative from the Gold Coast (Appiah, "Pan-Africanism"). In addition, one of the most influential early Pan-Africanist thinkers was Edward Wilmot Blydon, a man born in the Caribbean whose parents are from the Gold Coast (Walters, "Pan-Africanism"). In contrast to Pan Africanism's clear ideological statement that defines nation, self, and other through a racialized frame and broadly defines issues of belonging through the concept of Africanness as a biological category, Sekyi's characters explore the complex and multiple affiliations and boundaries that structure elite colonial identification in the early twentieth century, suggesting the conflicted way in which anticolonial cultural nationalism uses performances of whiteness as a way to recast colonial subjectivity into emergent nationalist identification. In this representation, whiteness traverses Africanness rather than opposes it. While Sekyi's cultural nationalist thinking positions uplift and revaluing of indigenous culture as the key aim of decolonization and the anticolonial political agenda, a key conundrum Sekyi's work opens up is whether decolonization structured through cultural nationalist thinking can allow for liberation that takes the form of a deep structural transformation. Sekyi's representations at the complex moment that Gold Coast nationalism emerges suggest a question that is still relevant today: How do we pull from multiple inheritances in an authentic way that fosters liberation as a practice of deep transformation that takes into account the tensions between and within different traditions? Ultimately, I argue Sekyi's representational strategies and main themes position whiteness as a racialized and contradictory interpolation that supports notions of modernity but negates the ultimate value of the black subject - a negation that cannot be overcome by achieving markers of

2 Pan-Africanism refers to the black nationalist project that began in the nineteenth century, which called for all Africans to be unified in a single state" (Appiah, Africana). Thus, Pan-Africanism is a product of key signifiers of modern identification in terms of invoking the tropes of citizenship, sovereignty, and the uniqueness of racialized identities. Appiah writes, "The Pan-Africanist movement began in the nineteenth century among intellectuals of African descent in North America and the Caribbean who thought of themselves as members of a single, "Negro," race. In this they were merely following the mainstream of nineteenth-century thought in North America and Europe, which developed an increasingly strong focus on the idea that human beings were divided into races, each of which had its own distinctive spiritual, physical, and cultural character. As a result, the earliest Pan-Africanists often limited their focus to sub-Saharan Africa: to the region, that is, whose population consists mostly of darkerskinned (or, as they would have said, "Negro") peoples (Appiah, "Pan-Africanism"). In this way, Pan-Africanism sought to fight anti-black racialism through engrained racial categories, a fairly romantic notion. In addition, the philosophical and institutional roots pull from a range of traditions, including European, North American (United States abolitionist thinking), and Caribbean (Appiah, "Pan-Africanism"). Finally, the philosophy is grounded in the essentially distinct or separate nature of racialized identification as well as freedom being contingent upon spatial separateness. For example, U.S. thinker Martin Delaney believed that black people could only flourish "in a country without white people" (Appiah, "Pan-Africanism"). 
success, such as speaking English, travelling internationally, or gaining professional or social success.

The representational practices in early Cape Coast anticolonial discourse suggest the role of whiteness in the identification practices of the Cape Coast elite. These include practices that allow Cape Coast elite to oppose colonial authority. In theoretical discourse, this is referred to as the politics of activity - the politics of what the Cape Coast elite do to constitute their identities and create systems and relationships of belonging. Belonging is a dynamic process in that it requires recognition from others. This recognition is based on rules and expectations. Moreover, in examining Sekyi's work, I argue that whiteness plays a key role in identity-consolidating representational practices and modes of recognition for Cape Coast elite. In "African Modes of Self-Writing," Achille Mbembe argues that "contemporary African modes of writing the self are inseparably connected with the problematic of self-constitution and the modern philosophy of the subject" (240). Identity-consolidating representational practices refer to modes of African selfrepresentation-representations that show what Africans do to establish their identifications and sense of self-and "self-styling" choices, including literary representations of African subjectivity (Mbembe, “African Modes of Self-Writing” 242). Sekyi's representations of Cape Coast elite suggest dignity, civilization, and economic success as key signifiers of the proper African. More broadly, the discursive investment of notions of dignity and success with whiteness continues to be an important theme in African and African diasporic literatures ${ }^{3}$. Such characterizations suggest how whiteness is a key signifier in the self-representations of black subjects to themselves, in their performances for others, and in their affiliative connections. Sekyi's characterization of Mr. Onyimdze, whose Western education undergirds his social position even as he grounds his self-representation in notions of an idealized Fanti past, suggests a cultural nationalist discourse in which (1) whiteness is deployed not to pass or to assume a different racial identification but instead to authorize the revaluing of African racial identification - to allow African identification to be assumed differently: proudly and with dignity and (2) Fanti culture is positioned to stand-in for national culture rather than positioning national culture as an expression of the multiplicity of local cultures, for example, an expression of both Fanti and Ashanti cultures.

An examination of the discursive, affiliative, and performative meanings of whiteness in relation to emergent postcolonial identification suggests that an interrogation of whitenesswhich traverses cultural, symbolic, economic, and psychological spheres - is a necessary part of the process of decolonization. This interrogation is necessary because, the weight of whitenessits authority, its seductiveness, its availability in establishing subject positions, its role in what Mbembe calls "the burden of the metaphysics of difference"-is still with us ("African Modes of Self-Writing" 240). Whiteness continues to serve as a key strategy in representing the African self, particularly representations of elite and aspiring elite subjects. In this way, whiteness is a key strategy in representing liberatory claims, where liberation is conceived as the attainment of key markers of modernity. As such, representations of a liberated African self are invested in

\footnotetext{
${ }^{3}$ For a recent example, see Toni Morrison's short story "Sweetness." Morrison writes a monologue of a character speaking to the reader, "I'm light-skinned, with good hair . . . . You should've seen my grandmother; she passed for white, married a white man, and never said another word to any of her children .... Some of you probably think it's a bad thing to group ourselves according to skin color - the lighter the better-in social clubs, neighborhoods, churches, sororities, even colored schools. But how else can we hold onto a little dignity?"
} 
notions of progress, defined as the ability to fulfill a meaningful destiny. Given modernity's founding myth of African difference, this destiny is a priori and a posteriori better than the key signifiers of the African: a degraded past of savagery, "slavery, colonization, and apartheid" (Mbembe "African Modes of Self-Writing" 242). Sekyi's work also suggests that the concept of liberation is invested in the notions of dignity; civilization; masculinity; and autonomy, defined as the ability to direct and provide options for one's present and future. As such, formulations of liberation significantly take up the key categories of modernity rather than challenging them. Given this conservative positioning of liberation, the subject positions allowed for through anticolonial struggles themselves become conservative, and whiteness plays a large role in this conservatism.

Through theater, Sekyi engages whiteness at a historically and culturally specific moment, exposing the representational strategies that inform self-making practices of early twentieth-century Gold Coast elites. The characters in "The Blinkards" represent various elites and the younger generation of aspiring elites who seek oppositional identification through the power of whiteness. For these characters, whiteness serves as a trope that collates notions of success, morality, and dignity. Sekyi's use of whiteness as a representational strategy that undergirds self-making also emphasizes performance, fluidity, circulation, and accumulation, suggesting also the sense of whiteness as a watershed — not a geographic/political boundary as boundaries are constructed in nationalist discourse - but an ecological/psychosocial dynamic, a space where several different affiliations, aspirations, and contestations that constitute selfmaking collect - a psychosocially meaningful doing. In this way, whiteness can be figured as an important watershed site where key concepts related to inclusion, marginalization, authenticity, power, authority, control, voice, and status are consolidated within the context of normative Gold Coast colonial beliefs, values, and institutions. In other words, concepts of whiteness served to undergird coastal elites' self-making, aspirations for progress, and articulation of their resistance to the racial caste system that undergirded colonial modernity.

\section{Whiteness and Postcolonial Identification}

Sekyi's use of visual theatrics reveals that whiteness as a signifier of power resides uneasily with racialized Fanti identification. In Black Skin, White Masks, Frantz Fanon identifies a key psychoaffective inheritance of colonialism as the dissonance created by resistance. Sekyi's work predates Fanon's analysis of the ways in which questioning colonial values and roles from a subjective position of embeddedness within the colonial system creates complex psychic dissonances - the meaningful proliferation of psychic disturbance becomes a key marker of postcolonial identification. These dissonances symbolically magnify DuBois's conception of double consciousness to the point where the sense of doubleness does not adequately define the subjective experience of the postcolonial subject. In The Souls of Black Folk (1903), Du Bois describes "double consciousness" as

this sense of always looking at one's self through the eyes of others, of measuring one's soul by the tape of a world that looks on in amused contempt and pity. One ever feels his two-ness, an American, a Negro; two souls, two thoughts, two unreconciled strivings; two warring ideals in one dark body, whose dogged strength alone keeps it from being torn asunder. The history of the American Negro is the history of this strife - this longing to attain self-conscious manhood, to merge his double self into a better and truer self. In this 
merging he wishes neither of the older selves to be lost. He does not wish to Africanize America, for America has too much to teach the world and Africa. He wouldn't bleach his Negro blood in a flood of white Americanism, for he knows that Negro blood has a message for the world. He simply wishes to make it possible for a man to be both a Negro and an American without being cursed and spit upon by his fellows, without having the doors of opportunity closed roughly in his face. (45-6)

Here Du Bois points to the entanglement of American (national), Negro (racial), and African (geo-political) identities in visual terms as a kind of gaze that functions as an internalized standard. In chapter five of Black Skin, White Masks, "The Lived Experience of the Black Man," Fanon himself suggests that he "existed in triple," drawing attention to how the representation of the psychic experience of fragmentation in the black self proliferates from double to triple to the multiplicity of dissonances that mark the increasing complexity of identifications for the postcolonial African subject (89). These key postcolonial dissonances are created by needing to accept the positive valences of whiteness as the condition of the possibility of progress and dignity while having to reject the negative valences of whiteness as promoting notions of black inferiority and an uncivilized African past. The rejection is necessary in order to not constitute identification through self negation. Given this ambivalence of whiteness, Sekyi's work poses questions still relevant today: How can the black subject deploy whiteness, which includes internalizing white supremacist values, to achieve success while also cultivating a self-concept grounded in a critical understanding of and respect for indigeneity? In this case, indigeneity is signified by an authenticity grounded in owning and being proud of a Fanti past. What is at stake in grounding liberatory modes of consciousness - representations of the liberated African subject -in the trope of whiteness is gaining the ability to sit at the table of modernity and to partake in what it has to offer while also losing the ability to oppose the key categories that ground subjection in violence, hierarchy, and inequity.

An analytical focus on how whiteness undergirds representations of emergent nationalist subjectivity reveals the primacy of visuality in the performance of oppositional identification. More important, it reveals the system of conflations that traverse and construct emergent postcolonial subjectivity. This system comprises not simply the binary conflations of indigeneity with inferiority and whiteness with superiority but complex associations that ance relate the African past to dignity and morality and also backwardness ---- and relate whiteness not only to progress, civility, modernity, and upward social mobility but also to racialized violence and exclusion. In other words, whiteness is a deeply fraught figure that collates notions of success, modernity, and progress as well as images of a failure of style with notions of alienation and exclusion. The failure of style is marked primarily by the absurdity related to how the audience perceives the characters who bear the visual markers of whiteness in terms of dress, behavior, and speech. The characters marked most visually by whiteness are also perceived as ridiculous by the characters marked as authentically Fanti in terms of their dress, language, or reverent manner of thinking about Fanti culture. Finally, the failure of style is embodied in the moral arc of the play in which the character most absurdly marked by visual whiteness suffer: Mrs. Borofosem is assaulted by her drunken servant, and her protégé, whom she is teaching to behave like a proper "white lady" and who has eschewed Fanti tradition to be engaged in the style she 
read about in an English novel, loses her baby (Sekyi 21). Mr. Borofosem, the male character most fraught by his intimate relation with the English language and increased comfort with the English style of dress, decides that native customs are better. For example, by the end of the play he decides that the native cloth is more comfortable than English-style dress if one is simply shown how to tie it properly and that sandals do not hurt the feet and thus represent a victory for "the rule of common sense" over the torture caused by the "regime of the boot" (Sekyi 161). This imagery shows a metonymic replacement of the colonial regime - and colonial modes of identification - with the image of the boot. The more authentic "native" expressions of identification relate cultural nationalism to rationality and respectability. This moral arc also creates an oppositional identification that is wholly backwards looking, pulling the way forward from as faithful a resurrection of the past as possible.

The oppositional and anticolonial ethos of the play espouses cultural nationalism as an antidote to the cultural degeneration caused by colonial rule. This is primarily communicated through the rhetoric throughout the play that opposes native culture to European culture, which is a source of alienation. As such, in Sekyi's literary representations of cultural nationalist identification, whiteness is a key structuring element of Gold Coast elites' and aspiring elites' experiences of alienation. The ultimate goal of decolonization is to foster liberatory consciousness or the existential lived experience of freedom. In African Modernities, African Studies scholars Jan-Georg Deutsch, Peter Probst, and Heike Schmidt argue that examination of social practices and aesthetic representational strategies of African modernity show how "people seek to overcome . . alienation . . . while using the very objects that embody that alienation" (12). Sekyi's characters suggest that he grounds his cultural nationalism in a critique of whiteness as an internalized structure - as a structure of identification and social binding. As such, Sekyi's cultural nationalism makes an intimate intervention into emergent practices of postcolonial identification.

Whiteness is leveraged in every subject position represented in the play-by characters who celebrate their English practices as well as those, such as Mr. Onyimdze, who eschew such cultural traffic. For example, the young Mr. Okadu, a carpenter's son, visits Mr. Onyimdze in Act One and asks him to teach him "some European things to make [him] like a white man" so he might win the hand of the young Miss Tsiba in marriage but her father will only let her marry a successful man "who has gone to England" (Sekyi 29). In Mr. Okadu's romance with Miss Tsiba, English education becomes the way he will fashion himself into an appropriate suitor for her. Even as Mr. Okadu asks for English education as a bid to bolster his position with Mr. Tsiba, he also shows the tensions that exist in his social positioning as well as the experiences of economic marginalization that inform his experience, as well as the broader situation of coastal elites in the play's historical moment. Before asking Mr. Onyimdze to teach him to be English, Mr. Okadu explains he was just fired because he called his boss "white savage" after the boss kicked him (Sekyi 26). In this context, "white" also has a negative valence and has the task of signifying both civility and the savagery of the racial caste system, specifically the violence through which it is enacted as a daily social and economic practice, as well as the way in which it informs affiliations and sanctions relations with others (who is acceptable and civilized and who is not and therefore should be ignored).

In this way, Sekyi deploys whiteness as a practice that tries to close the gaps created by colonial exclusion. The main currency that allows the characters to belong or make a bid for 
social status is whiteness - the conflation of English, British, and European practices to stand in for key notions of African modernity as imagined in the play: respectability, morality, progress, and civilization. Mr. Onyimdze confesses that, despite his affinity for Fanti culture, sometime he finds "it easier to speak English" (Sekyi, 35). He notes, "I suppose that is to be expected of us social hybrids, born into one race, and brought up to live like members of another race" (Sekyi, 35). Even if Mr. Onyimdze did not find himself intimately interpolated by the English language on a personal level, slipping "into it unawares," his social standing in the eyes of the elite and aspiring elite characters, such as Mr. Okadu, is heightened because he has traveled and been educated in Europe. As a character, Mr. Onyimdze opens up a key question about the aim of Sekyi's cultural nationalism, which in some sense aimed to consolidate a pure national (Fanti) space: Even if this goal were possible and desirable - if the transnational flows of capital and culture could be molded into pure spaces-how can a social hybrid go about constructing such a pure space? As a key representational strategy used in Anglophone literary traditions, whiteness poses an urgent question about the boundaries that working within a discourse of Western/white superiority puts on forms of self-making.

Sekyi's deployment of whiteness relies heavily on tropes of sight, beginning with the title itself. According to the Oxford English Dictionary, the term blinkard is an insult that literally refers to someone with the nervous tic of blinking all the time, suggesting that blinking acts as a physical barrier to seeing clearly. Figuratively, the term refers to someone who "lacks intellectual perception" or is willfully dismissive of the facts of a situation $(O E D)$. Playing with all the associations this word puts into play-visuality and subjectivity, representation and nostalgia, reflection and revelation, and image and perception-Sekyi frames internalized identification with whiteness as a form of false consciousness or not being able to see clearly in the more profound sense of wisdom and the epistemology of self-making. Sekyi's invocation of tropes of vision invites investigation of the social practices of self-making, vision, imagination, wisdom, and meaning making. As a representational strategy, Sekyi's use of tropes of sight suggests the visual economy of whiteness, which makes color as a signifier of race a key aspect of experiences of modernity and, in particular, the sense of enfranchisement and citizenship. Sekyi offered his audience a comic and complex view of this obsession with whiteness harbored by the educated nationalist elite who were at once fighting the racism and political and economic exclusion of the colonial state and negotiating the role of traditional leaders in both the colonial state and emergent nationalist movement through the figure of Mr. Oyimdze, the absurd creature interpolated by modernity as whiteness and also having a nostalgia for traditional culture. As scholar Richard Rathbone points out, this negotiation is not between the opposing categories of tradition and modernity but between the category of tradition as it is reinvented to serve the ideological and practical needs of the moment, in this case, the project of anticolonial consciousness in the form of emergent national consciousness ${ }^{4}$. Its intimate entanglement with

\footnotetext{
4 "The contingent history of colonialism shows that many West African colonial regimes could and did, in one fashion or another, restore or reinvent chieftaincy to play a subaltern role in the evolving colonial states. ... some of the most significant arenas of African politics were to be dominated by sometimes violent contests between chieftaincy and radical nationalism. These were not contests between tradition and modernity but between different recensions of modernity," (Rathbone, "West Africa: Modernity and Modernization," African Modernities: Entangled Meanings in Current Debate, Portsmouth: Heinemann, 2002, 27).
} 
whiteness and conservative framing of African-ness limit the liberatory power of this emergent form of nationalism, calling us to continue to imagine liberatory forms of self-making in Africa and beyond. 


\section{Works Cited}

Appiah, Kwame Anthony. "Pan-Africanism." Africana: The Encyclopedia of the African and African American Experience, Second ed. Oxford: Oxford University Press, 2004. Web. 10 Sept 2015.

Baku, Kofi. "Kobina Sekyi of Ghana: An Annotated Bibliography of His Writings." The International Journal of African Historical Societies 24.2 (1991). 369-81. Web. 8 June 2014.

"Blinkard." Oxford English Dictionary. London: Oxford University Press, 2014. Web. 3 Aug. 2014.

Burns, Robert. "To a Louse: Upon Seeing One on a Lady's Bonnet at Church.” Burns Country. Web. 5 Feb. 2015.

Cuoma, Chris and Kim Hall, eds. Whiteness: Feminist Philosophical Reflections. Lanham: Rowman and Littlefield Publishers, Inc., 1999. Print.

Du Bois, W.E. B. The Souls of Black Folk. New York: Signet, 1995. Print.

Fanon, Frantz. Black Skin, White Masks. New York: Grove Press, 1967. Print.

---Black Skin, White Masks. New York: Grove/Atlantic, Inc. Kindle Edition, 2008.

Hooks, bell. "Choosing the Margin as a Space of Radical Openness." Yearnings: Race, Gender and Cultural Politics. Boston: South End Books, 1989. 145-154. Print.

Mbembe, Achille. "African Modes of Self Writing." Public Culture 14.1: 2002. 239-73. Print. Osei-Nyame, Kwadwo. "Pan-Africanist Ideology and the African Historical Novel of SelfDiscovery: The Examples of Kobina Sekyi and J. E. Casely Hayford." Journal of African Cultural Studies 12.2 (1999): 137-153. Print.

Pierre, Jemima. The Predicament of Blackness: Postcolonial Ghana and the Politics of Race. Chicago: University of Chicago Press, 2013. Print.

Probst, Peter, Jan-George Deutsch, and Heike Schmidt. "Cherished Visions and Entangled Meanings." African Modernities: Entangled Meanings in Current Debate, eds. Jan-Georg Deutsch, Peter Probst, Heike Schmidt. New Hampshire: Heinemann, 2002. 1-17. Print.

Rathbone, Richard. "West African: Modernity and Modernization," African Modernities: Entangled Meanings in Current Debate, eds. Jan-Georg Deutsch, Peter Probst, Heike Schmidt. Portsmouth: Heinemann, 2002. 18-30. Print.

Rosenthal, William J. "Lorgnettes." In Spectacles and Other Vision Aids: A History and Guide to Collecting. San Francisco: Norman Publishing, 1996. 118-137. Web. 30 April 2018.

Sekyi, Kobina. The Blinkards. London: Heinemann, 1974. Print.

Walters, Ronald. "Pan-Africanism." Encyclopedia of African American History, 1896 to the Present: From the Age of Segregation to the Twenty-first Century. Ed. Paul Finkelman. New York: Oxford UP, 2008. Oxford African American Studies Center. Web. 10 Sep 2015.

Wood, Casey Albert, ed. The American Encyclopedia and Dictionary of Ophthalmology, Vol. 7. Chicago: Cleveland Press, 1915. Web. 30 April 2018. 